\title{
PENGEMBANGAN MODUL BERBASIS INQUIRY LAB UNTUK MENINGKATKAN KEMAMPUAN MENGANALISIS PADA MATERI SISTEM GERAK KELAS XI IPA
}

\author{
Ferida Dwi Karlina $^{1}$, Sajidan ${ }^{2}$ dan Puguh Karyanto ${ }^{3}$ \\ ${ }^{1}$ Magister Pendidikan Sains, Fakultas Keguruan dan Ilmu Pendidikan, Universitas Sebelas Maret \\ Surakarta, 57126, Indonesia \\ ferik2447@gmail.com \\ ${ }^{2}$ Magister Pendidikan Sains, Fakultas Keguruan dan Ilmu Pendidikan, Universitas Sebelas Maret \\ Surakarta, 57126, Indonesia \\ sajidan@fkip.uns.ac.id \\ ${ }^{3}$ Magister Pendidikan Sains, Fakultas Keguruan dan Ilmu Pendidikan, Universitas Sebelas Maret \\ Surakarta, 57126, Indonesia \\ puguh@staff.uns.ac.id
}

\begin{abstract}
Abstrak
Tujuan penelitian yaitu: 1) mengetahui karakteristik modul berbasis Inquiry Lab untuk memberdayakan kemampuan menganalisis pada materi sistem gerak, 2) mengetahui kelayakan modul berbasis Inquiry Lab untuk memberdayakan kemampuan menganalisis pada materi sistem gerak, 3) mengetahui keefektivan modul berbasis Inquiry Lab untuk memberdayakan kemampuan menganalisis pada materi sistem gerak di SMA negeri 1 Ngawi. Pengembangan modul berbasis Inquiry Lab mengacu pada 9 langkah model research and development (R\&D) dari Borg and Gall meliputi: 1) penelitian dan pengumpulan data, 2) perencanaan, 3) pengembangan produk, 4) uji coba produk awal, 5) revisi produk I, 6) uji coba lapangan, 7) revisi produk II, 8) uji coba lapangan operasional, 9) revisi produk akhir. Analisis hasil penelitian menggunakan dua teknik yaitu deskriptif kualitatif dan diskriptif kuantitatif. Hasil penelitian tentang: 1) Karakteristik Modul Biologi Inquiry Lab pada Materi Sistem Gerak yang dikembangkan menggunakan sintak Inquiry Lab, meliputi observasi, manipulasi, generalisa, verifikasi dan aplikasi. Setiap kegiatan pembelajaran siswa di arahkan untuk menemukan konsep melalui aktivitas laboraturium, 2) Hasil validasi Modul Biologi berbasis Inquiry Lab pada materi sistem gerak dapat digunakan sebagai bahan ajar baru di sekolah. Kelayakan didasarkan atas penilaian terhadap modul melalui uji validasi ahli materi 94,80\% dengan kualifikasi sangat baik, validasi ahli pengembangan modul $84,21 \%$ dengan kualifikasi sangat baik, validasi ahli perangkat 96,55\% dengan kualifikasi sangat baik, validasi ahli keterbacaan $75 \%$ dengan kualifikasi baik. Uji kelompok kecil pengguna lapangan (guru dan siswa), validator praktisi (guru) 90,06\% dengan kualifikasi sangat baik, dan uji dari lapangan terbatas 81,88\% dengan kualifikasi sangat baik, dan uji keefektifan yang telah sesuai dengan tujuan pengembangan, 3) Keefektifan Modul Biologi berbasis Inquiry Lab pada materi sistem gerak telah efektif dalam memberdayakan kemampuan menganalisis siswa karena menunjukkan adanya perbedaan hasil posttest antara kelas modul dan kelas exiting learning dengan nilai Sig. $=0.000<\alpha=0.05$ dengan rata-rata masing-masing kelas modul 75,83 dan kelas exiting learning 69,83.
\end{abstract}

Kata Kunci: Modul, Inquiry Lab, research and development, kemampuan menganalisis

\section{Pendahuluan}

Kegiatan laboratorium merupakan komponen yang penting dalam pembelajaran IPA. Menurut Lazarowitz \& Tamir dalam Wiyanto (2006), kurikulum berbasis inquiry mengalokasikan waktunya sekitar 50\% untuk kegiatan laboratorium. Namun beberapa penelitian menunjukkan bahwa kegiatan laboratorium yang dikembangkan masih bersifat verifikasi, yaitu membuktikan konsep atau prinsip yang telah dibahas sebelumnya dengan kegiatan lab yang masih bersifat teacher centered. Kegiatan praktikum yang seperti ini tidak mampu mengembangkan keterampilan kemampuan berpikir siswa dalam tahap yang lebih tinggi. 
Kegiatan laboratorium pada hakikatnya ditujukan untuk membantu siswa mengembangkan pemahaman, kemampuan kognitif, berpikir kreatif dan sikap ilmiah melalui keterlibatannya dalam aktivitas atau kegiatan (Novack, Gangoli, Hodson, dalam Suma 2005). Kegiatan laboratorium adalah salah satu metode pengajaran yang paling penting untuk memberikan pembelajaran yang efektif dan bermakna dalam pendidikan sains. Tamir (Koray \& Köksal, 2009) mengatakan kegiatan laboratorium didasarkan pada partisipasi aktif siswa dalam proses pengumpulan data dan memberikan analisis dari fakta-fakta dari hasil yang diperoleh. Selain itu, juga dapat memberikan kesempatan kepada siswa untuk meningkatkan pemecahan masalah mereka dan keterampilan penyelidikan, untuk melakukan generalisasi yang tepat tentang poin penting dalam ilmu pengetahuan, untuk memperoleh pengetahuan ilmiah dan untuk memegang sikap positif terhadap ilmu pengetahuan.

Menurut Wenning (2014) terdapat 6 level model inquiry mulai dari yang bertaraf rendah sampai yang membutuhkan kemampuan intelektual yang tinggi, yaitu : (1)discovery learning, (2)interactive demonstration, (3)inquiry lesson, (4)inquiry labs, (5)real-world application, dan (6)hypotetical inquiry. Aktivitas siswa dalam inkuiri lab membantu siswa belajar dan memahami proses dan ketrampilan berpikir layaknya ilmuwan dan memahami karakteristik penelitian ilmiah. Siswa melakukan komtrol sendiri dalam proses pembelajaran melalui menjawab pertanyaanpertanyaan yang dikemas dalam lembar Kerja Siswa (LKS). Indikator-indikator yang menjadi materi pertanyaan dalam LKS adalah: (1) mendorong keterlibatan mental, penggunaan ketrampilan berpikir tingkat tinggi, (3) mendorong pemusatan perhatian siswa untuk mengumpulkan dan menginterpretasi data, (4) menuntun siswa menemukan konsep, prinsip, dan hukumhukum baru melalui kreasi dan kontrol sendiri dalam eksperimen, (5) mendorong siswa menerapkan prosedur ilmiah.
Pembelajaran berbasis inkuiri laboratorium menekankan pada aktivitas dalam membantu siswa belajar dan memahami proses dan keterampilan berpikir layaknya ilmuan dan memahami karakteristik penelitian ilmiah (Wenning, 2010 \& Khan, et al, 2011). Model pembelajaran inkuiri laboratorium memiliki sejumlah langkah termasuk aktif mengidentifikasi suatu topik atau masalah, menghasilkan pertanyaan yang akan diteliti, menyelidiki masalah dengan melakukan penelitian yang relevan, berpikir kritis tentang masalah yang akan dipecahkan, menjawab pertanyaan yang diajukan, menarik kesimpulan dan merefleksikan pada proses penyelidikan (Vajoczki, S. et al, 2011).

Kemampuan analisis juga memiliki peranan yang sangat penting terhadap tercapainya tujuan belajar. Kemampuan analisis merupakan suatu kemampuan dasar yang harus dimiliki oleh siswa. Kemampuan analisis adalah ketrampilan menguraikan sebuah struktur ke dalam komponenkomponen agar mengetahui pengorganisasian struktur tersebut. Menganalisis adalah memisahkan materi kedalam bagian-bagian yang diperlukan, mencari hubungan antar bagiannya, mampu mengenali komponenkomponennya, hubungan dan pengorganisasian antar komponen, serta membedakan fakta dari khayalan, namun selama ini kemampuan analisis belum diperhatikan sebagai salah satu faktor penentu keberhasilan belajar (Sofan Amri dan Iif Khoiru Ahmadi, 2010).

Kemampuan menganalisis merupakan salah satu kemampuan kognitif tingkat tinggi yang penting untuk dikuasai siswa dalam pembelajaran. Anderson dan Krathwohl (2001) telah merevisi penggunaan Taksonomi Bloom sebagai kerangka konseptual ketrampilan berpikir dengan mengubah sistem klasifikasi Bloom yang asli menjadi dua dimensi pengetahuan melibatkan pengetahuan faktual, konseptual, prosedural dan metakognisi. Dimensi proses kognitif meliputi mengingat, memahami, mengaplikasi, menganalisis. Mengevaluasi dan mencipta menggantikan pengetahuan, pemahaman, aplikasi, analisis, sintesis, dan evaluasi pada Taksonomi Bloom 
yang lama. Pohl (2000) mengungkapkan bahwa dalam Taksonomi Bloom revisi ketrampilan yang melibatkan analisis, evaluasi, dan mencipta dianggap sebagai ketrampilan berpikir tingkat tinggi. Anderson dan Krathwohl (2001) menyatakan indikator untuk mengukur ketrampilan berpikir tingkat tinggi meliputi menganalisis, mengevaliasi dan mencipta.

Fakta di sekolah yang menggambarkan kemampun berpikir siswa Indonesia ditunjukkan pada penilaian The Program for International Student Assesment (PISA). Indonesia selalu menempati level bawah dibanding dengan negara-negara partisipan dunia. pada 2012, tercatat Indonesia menduduki peringkat 64 dari 65 negara yang berpartisipasi dengan skor siswa Indonesia 382 dari skor rata-rata dunia 500. Selain itu penelitian yang dilakukan Astika (2013) di Bali menunjukkan bahwa kemampuan penguasaan sains siswa masih rendah. Permasalahan lain yang dihadapi siswa adalah kemandirian belajar.

Kurangnya kualitas pembelajaran berdampak pada pencapaian hasil belajar yang rendah. Salah satu pengukuran hasil belajar adalah Ujian Nasional (UN). Hasil UAN Biologi SMA Negeri 1 Ngawi tahun 2013/2014 menunjukkan pada materi Struktur dan Fungsi Organ terutama sistem gerak ratarata nilai yang diperoleh yaitu 51,36 untuk tingkat nasional; 64,04 untuk tingkat propinsi; 57,91 untuk tingkat kota; dan 64,45 untuk tingkat sekolah. Hasil ulangan harian siswa menunjukkan nilai rata-rata 64,50, dimana nilai ini berada di bawah KKM yaitu 78,00.

Fakta di lapangan menunjukkan rendahnya penguasaan sains berhubungan erat dengan kualitas pembelajaran. Berdasarkan analisis delapan Standar Nasional Pendidikan (SNP) yang meliputi standar isi, standar proses, standar kompetensi kelulusan, standar pendidik dan tenaga kependidikan serta standar penilaian (Badan Akreditasi Nasional, 2012) menunjukkan bahwa GAP pada Standar 1 sebesar 0,93\%; Standar 2 sebesar 1,85\%; Standar 3 sebesar 0,46; Standar 4 sebesar 1,85\%; Standar 5, 6 dan 7 tidak memiliki GAP; dan Standar 8 sebesar 1,39\%. Data tersebut menunjukkan bahwa pada Standar 8 yaitu Standar penilaian yang terdapat 13 komponen memiliki GAP yang tergolong tinggi. Adanya GAP ini dapat disimpulkan bahwa kurang maksimalnya penyusunan dan pelaksanaan pada tiap-tiap indikator.

Capaian UN sebagai hasil belajar tidak dapat dipisahkan dari proses pembelajaran. Hasil observasi proses belajar mengajar di SMA Negeri 1 Ngawi diperoleh bahwa dari 61 siswa kelas XI IPA 4 dan XI IPA 5 ada $73,77 \%$ siswa belum memiliki buku wajib pegangan untuk siswa. Masih banyak siswa mencari sumber belajar melalui internet. Ada juga dari 61 siswa dari dua kelas kelas XI IPA 4 dan XI IPA 5 ada $26,66 \%$ siswa yang mempunyai buku wajib pegangan tetapi masih belum memenuhi berpikir tingkat tinggi dan ketrampilan proses sains terutama kemampuan menganalisis. $13,11 \%$ siswa menyatakan bahwa buku wajib pegangan menarik, sementara $9,83 \%$ siswa menyatakan buku pegangan yang digunakan kurang menarik dan $31,14 \%$ siswa menyatakan buku tersebut cukup berkaitan dengan kehidupan di masyarakat sehari-hari. Guru menggunakan buku ajar yang bersifat umum. Materi dalam buku ajar kurang ringkas. Buku ajar berupa fotokopy. 56,25\% siswa menginginkan materi di buku ajar lengkap. 53,12\% siswa menginginkan materi di buku ajar ringkas, $71,87 \%$ menginginkan buku ajar lebih menarik seperti gambar dan warna dan $25 \%$ siswa huruf dalam buku ajar jelas.

Pembelajaran inkuiri merupakan rangkaian kegiatan pembelajaran yang menekankan pada proses berpikir kritis dan analitis untuk mencari dan menemukan sendiri jawaban dari suatu masalah yang dipertanyakan. Wenning (2012) membagi model pembelajaran inkuiri menjadi enam tahapan yaitu: discovery learning; interactive demonstration; inquiry lesson; inqury laboratory; real world application; dan hypothetical inquiry. Hasil survey di SMA Negeri 1 Ngawi bahwa perolehan data saat tes kemampuan inkuiri yaitu 90,62\% siswa menguasai inkuiri level 1 (discovery learning) dengan nilai rata-rata nilai 80,40; siswa menguasai inkuiri level 2 (interactive 
demonstration) dengan nilai rata-rata 84,03 ; siswa menguasai inkuiri level 3 (inquiry lesson) dengan rata-rata nilai 86,29 , dan siswa kurang menguasai inkuiri level 4 (Inquiry Lab) dengan nilai rata-rata 67,62. Kemampuan inkuiri siswa pada level 1, level 2, level 3 termasuk kategori baik, sedangkan pada level 4 kemampuan inkuiri siswa dalam kategori kurang baik (Sugiyono, 2010 : 144).

Berdasarkan latar belakang di atas, maka judul penelitian yang di pecahkan adalah "Pengembangan Modul berbasis Inquiry Lab Pada Materi Sistem Gerak Untuk Memberdayakan Kemampuan Menganalisis pada Kelas XII IPA SMA Negeri 1 Ngawi.

\section{Metode Penelitian}

Model penelitian dan pengembangan (Research \& Development) yang diterapkan mengacu pada tahapan menurut Borg \& Gall (1983). Pendekatan penelitian dan pengembangan merupakan penelitian yang berorientasi untuk mengembangkan dan memvalidasi produk-produk yang digunakan dalam penelitian.

Langkah-langkah dalam Research \& Development (R\&D) menurut Borg \& Gall (1983) sebagai berikut: 1) Research and information collecting (penelitian dan pengumpulan data); 2) Planning (perencanaan); 3) Develop preliminary form product (pengembangan produk awal); 4) Preliminary field test (uji coba lapangan awal); 5) Main product revision (revisi produk I); 6) Main field testing (uji coba lapangan utama); 7) Operational product revision (revisi produk II); 8) Operational field testing (uji lapangan operasional); 9) Final product revision (revisi akhir); 10) Dissemination and implementation (penyebaran dan implementasi). Dalam penelitian ini dapat menggunakan sampel yang tidak terlalu besar dan diperbolehkan mengembangkan sampai tahapan tertentu sesuai dengan kebutuhan peneliti (Emzir, 2012). Pada penelitian ini hanya dilakukan sembilan tahapan dari sepuluh tahapan sebagai keterbatasan penelitian.

Studi lapangan dilakukan melalui observasi di SMA Negeri 1 Ngawi untuk mengetahui kondisi buku dan modul yang biologi yang digunakan dan informasi tentang materi yang sulit diserap siswa. Informasi terkait buku dan modul yang diperoleh mencakup isinya terdiri dari tujuan, materi, kegiatan, dan soal evaluasi.

Analisis buku dan modul di SMA Negeri 1 Ngawi dilakukan dengan cara menilai kesesuaian isi dengan indikator pembelajaran yang dikembangkan dari aspek Inqury Lab dan dimensi pengetahuan. Analisis tentang materi yang sulit diserap siswa dilakukan melalui wawancara dengan guru, pemberian angket pendapat siswa.

Subyek uji coba awal dilakukan oleh masing-masing satu orang ahli materi biologi dan ahli pembelajaran. Kedua ahli menjadi validator dengan kualifikasi pendidikan minimal S2 di bidang masing-masing. Validator adalah dosen Program Studi Pendidikan Sains Program Pascasarjana Universitas Sebelas Maret. Data hasil uji validasi ahli berupa data kualitatif yang kemudian dianalisis secara deskriptif untuk dasar revisi draft modul. Kriteria penilaian dari Depdiknas (2008).

Hasil uji validasi ahli dianalisis menggunakan analisis deskriptif. Analisis deskritif kualitatif digunakan untuk data pendapat, kritik dan saran. Kemudian untuk data nilai pensekoran dianalisis secara deskriptif kualitatif yaitu berupa kuantitatif dengan statistik. Adapun rumus analisis deskriptif kuantitatif dari lembar masingmasing lembar validasi dan pedoman pengambilan keputusan revisi adalah sebagai berikut:

$$
\mathrm{V}=\frac{T S E V}{S \max } x 100 \%
$$

Keterangan

$\mathrm{V}=$ Validitas

TSEV = Total Skor Empirik Validator

$\mathrm{S} \max =$ Skor maksimal yang diharapkan

Tabel 2 Pengambilan Keputusan Revisi

\begin{tabular}{ccc}
\hline $\begin{array}{c}\text { Tingkat } \\
\text { Pencapaian }\end{array}$ & Kualifikasi & Keterangan \\
\hline $\mathbf{8 1 - 1 0 0}$ & Sangat Baik & Tidak Perlu Direvisi \\
$\mathbf{6 1 - 8 0}$ & Baik & Tidak Perlu Direvisi \\
$\mathbf{4 1 - 6 0}$ & Cukup Baik & Direvisi \\
$\mathbf{2 1 - 4 0}$ & Kurang Baik & Direvisi \\
$\mathbf{0 - 2 0}$ & Sangat Kurang & Direvisi \\
\hline & & (Suwastono, 2011)
\end{tabular}

(Suwastono, 2011) 
Uji lapangan operasional dilakukan untuk mengetahui keefektivitasan produk berupa modul yang dibuat yaitu modul berbasis Inquiry Lab kelas pada materi Sistem Gerak yang diterapkan dalam kuasi eksperimen dengan penjelasan (Sugiyono, 2012) sebagai berikut :

Desain penelitian dapat digambarkan pada tabel 3 sebagai berikut:

Tabel 3 Desain Penelitian "Pretest-Postest Nonequivalent Control Group Desaign"

\begin{tabular}{cccc}
\multicolumn{4}{c}{ Control Group Desaign” } \\
\hline Kelompok & Pretes & Perlakuan & Postes \\
\hline Kelas Modul & $\mathrm{O} 1$ & $\mathrm{X}_{1}$ & $\mathrm{O} 3$ \\
Exiting Learning & $\mathrm{O} 2$ & $\mathrm{X}_{2}$ & $\mathrm{O} 4$ \\
\hline
\end{tabular}

\footnotetext{
Keterangan:

O1 : pelaksanaan pretes kelas modul

O2 : pelaksanaan postes Exiting Learning

$\mathrm{X} 1$ : pembelajaran dengan modul Inquiry Lab

$\mathrm{X} 2$ : pembelajaran tanpa modul Inquiry Lab

O3 : pelaksanaan postes kelas modul

O4 : pelaksanaan postes Exiting Learning
}

\section{Hasil Penelitian dan Pembahasan}

Data yang diperoleh dalam penelitian dan pengembangan antara lain data analisis kebutuhan, data validasi ahli dan praktisi, data hasil uji coba lapangan dan data uji operasional. Data analisis kebutuhan meliputi tingkat pemenuhan standar nasional pendidikan (SNP) di SMA Negeri 1 Ngawi, analisis bUKU yang digunakan guru. Analisis SNP mengenai 8 Standar Pendidikan Nasional digunakan untuk mengetahui standar yang dicapai oleh SMA Negeri 1 Ngawi. Hasil SNP disajikan pada Gambar 1

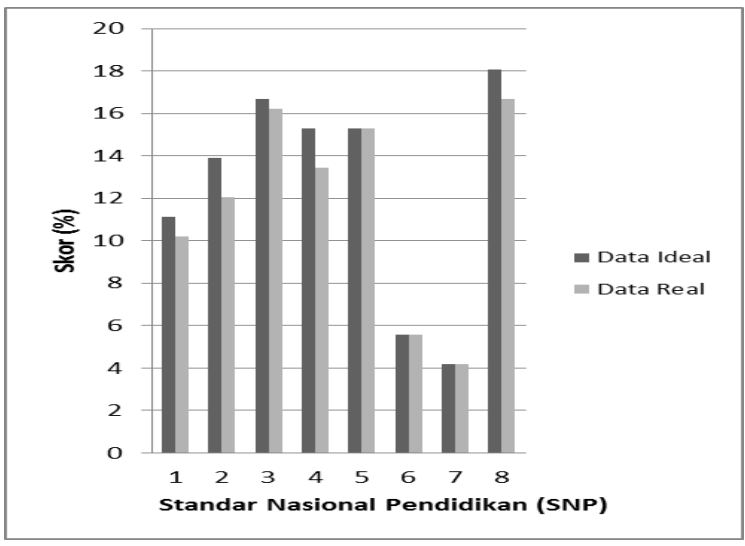

Gambar 1. Skor Implementasi 8 SNP di SMA Negeri 1 Ngawi
Hasil 8 SNP menunjukkan adanya GAP pada standar proses adalah $1,85 \%$ dan standar penilaian adalah $1,39 \%$. Analisis buku yang digunakan guru dilakukan untuk mengetahui presentase penggunaan tingkatan Taksonomi Bloom, dalam pembelajaran biologi, kurangnya pemenuhan tiga aspek kemampuan menganalisis pada aspek isi (menganalisis unsur, menganalisis hubungan, menganalisis prinsip-prinsip organisasi) seperti yang tercantum pada tabel 4

Tabel 4 Rata-rata hasil analisis bahan ajar di SMA Negeri 1 Ngawi

\begin{tabular}{clc}
\hline $\begin{array}{c}\text { Bahan } \\
\text { Ajar }\end{array}$ & \multicolumn{1}{c}{$\begin{array}{c}\text { Aspek Kemampuan } \\
\text { Menganalisis }\end{array}$} & $\begin{array}{c}\text { Aspek Buku } \\
\text { (tujuan, materi, } \\
\text { kegiatan, soal } \\
\text { evaluasi) (\%) }\end{array}$ \\
\hline Buku I & Menganalisis unsur & $30 \%$ \\
& $\begin{array}{l}\text { Menganalisis } \\
\text { Hubungan }\end{array}$ & $29,16 \%$ \\
& $\begin{array}{l}\text { Menganalisis Prinsip- } \\
\text { prinsip organisasi }\end{array}$ & $5,77 \%$ \\
Buku II & $\begin{array}{l}\text { Menganalisis unsur } \\
\text { Menganalisis }\end{array}$ & $30 \%$ \\
& Hubungan & $27,13 \%$ \\
& $\begin{array}{l}\text { Menganalisis Prinsip- } \\
\text { prinsip organisasi }\end{array}$ & $9,05 \%$ \\
\hline
\end{tabular}

Berdasarkan data di atas hasil penilaian analisis bahan ajar di SMA Negeri 1 Ngawi buku I pada aspek menganalisis unsur keseluruahan aspek buku sebesar 30\%, pada aspek menganalisis hubungan keseluruhan aspek buku sebesar 29,16\%, pada aspek menganalisis prinsip-prinsip organisasi keseluruhan aspek buku sebesar 5,77\%, sedangkan pada buku II pada aspek menganalisis unsur keseluruahan aspek buku sebesar 30\%, pada aspek menganalisis hubungan keseluruhan aspek buku sebesar $27,13 \%$, pada aspek menganalisis prinsipprinsip organisasi keseluruhan aspek buku sebesar $9,05 \%$.

Tahap uji coba permulaan merupakan tahap penilaian modul yang dilakukan oleh validasi ahli. Validasi dilakukan oleh ahli materi diperoleh rata-rata dari keseluruhan 
aspek sebesar 94,80\% yang dikategorikan "Sangat Baik" tetapi masih perlu dilakukan perbaikan. Validasi ahli pengembangan desain modul diperoleh persentase untuk keseluruhan aspek sebesar $84,21 \%$ yang dikategorikan "Sangat Baik" tetapi masih perlu dilakukan sedikit perbaikan pada gambar yang ada pada modul dari segi warna dan kejelasan gambar. Validasi ahli bahasa atau keterbacaan modul diperoleh persentase skor untuk keseluruhan aspek sebesar $75 \%$ yang dikategorikan Baik sehingga modul masih perlu dilakukan sedikit perbaikan atau direvisi perlu penyesuaian penggunaan bahasa yang sesuai dengan gaya bahasa formal untuk siswa SMA. Validasi ahli pengembangan perangkat pembelajaran diperoleh persentase skor untuk keseluruhan aspek sebesar 96,55\% yang dikategorikan Sangat Baik tetapi masih perlu dilakukan sedikit perbaikan pada penilaian.

Berdasarkan hasil penilaian modul oleh validator praktisi guru biologi, diperoleh oleh siswa dengan instrumen penilaian berupa kuisioner, diperoleh persentase rata-rata keseluruhan sebesar $81,88 \%$ dengan kriteria sangat baik. Siswa menjelaskan bahawa modul sudah cukup baik karena dilengkapi dengan gambar yang sudah berwarna sehingga menarik untuk dibaca tetapi ada beberapa tulisan yang kurang sehingga perlu diperbaiki lagi. Menurut siswa bahasa yang digunakan ada yang masih belum bisa dipahami. Uji lapangan oprasional/keefektifan bertujuan untuk mengetahui keefektifan modul berbasis Inquiry Lab pada materi sistem gerak pada manusia untuk memberdayakan kemampuan menganalisis siswa. Tahap uji coba oprasional dilakukan dengan setting kuasi eksperimen menggunakan dua kelas dengan perlakuan berbeda.

Hasil kemampuan menganalisis siswa dilakuakan data pada pre-test dan post-test untuk kelas modul dan kelas Exiting learning yang dapat dilihat pada Tabel 5

Tabel 5 Hasil Kemampuan Menganalisis siswa untuk Kelas Modul dan Kelas Exiting learning jumlah skor 95 untuk aspek tampilan modul

\begin{tabular}{clccc}
\hline $\begin{array}{c}\text { Data hasil } \\
\text { belajar } \\
\text { siswa }\end{array}$ & \multicolumn{1}{c}{ Kelas } & $\begin{array}{c}\text { Jumlah } \\
\text { siswa }\end{array}$ & $\begin{array}{c}\text { Nilai } \\
\text { Max }\end{array}$ & Rata-rata \\
\hline Pre- test & $\begin{array}{l}\text { Modul } \\
\text { Exiting learning }\end{array}$ & 30 & 100 & 63,50 \\
Post- test & Modul & & & 55,50 \\
Exiting learning & 30 & 100 & 6,83 \\
\end{tabular}

dengan persentase $98,95 \%$ termasuk kriteria sangat baik. Jumlah skor untuk aspek materi yaitu 154 dengan persentase $91,67 \%$ termasuk kriteria sangat baik. Jumlah skor untuk aspek keterbacaan yaitu 40 dengan persentase $83,33 \%$ termasuk kriteria sangat baik. Jumlah skor total penilaian yaitu 281 dari 312 dengan persentase 90,06\% termasuk kriteria Sangat Baik tapi masih perlu penambahn materi yang relevan dan menambahkan pengertian kelainan pada sistem gerak lebih jelas.

Uji coba lapangan terbatas dilakukan kepada lima belas orang siswa SMA Kelas XII IPA. Berdasarkan hasil kuisioner uji coba lapangan terbatas untuk penilaian modul yang dilakukan kepada lima belas siswa SMA jurusan IA disekolah yang berbeda dan uji coba

lapangan terbatas ini dilakukan di SMA Negeri 1 Ngawi. Pada penilaian modul yang dilakukan
Berdasarkan hasil data di atas dapat dilihat adanya peningkatan rata-rata kemampuan menganalisis siswa setelah pembelajaran pada kelas modul lebih tinggi dari kelas Exiting learning dengan adanya penurunan standar deviasi. Nilai standar deviasi yang cukup besar (dari mean/rata-rata) menunjukkan adanya variasi yang cukup besar, begitu pula sebaliknya (Santoso, 2012). Kelas modul nilai tertinggi pre-test 75 dan nilai terendah pre-test 60 dari nilai maksimal 100 sehingga memiliki rata-rata 64 dan standar deviasi 7, nilai tertinggi post-test 90 dan nilai terendah post-test 65 dari nilai maksimal 100 sehingga memiliki rata-rata 76 dan standar deviasi 6. Exiting learning memiliki nilai tertinggi pre-test 70 dan nilai terendah pre-test 40 dari nilai maksimal 100 dan memiliki rata- 
rata 56 , standar deviasi 10 , nilai tertinggi posttes 85 dan terendah 60 dari nilai maksimal 100 sehingga memiliki rata-rata 70 dan standar deviasi 7. Hal itu berarti bahwa rata-rata posttest yang tinggi pada kelas modul dan standar deviasi yang rendah mengindikasikan sebaran nilai siswa mendekati nilai rata-rata, penurunan standar devisiasi dengan disertai peningkatan rata-rata dari nilai pre-test dan post-test mengindikasikan bahwa scaffolding yang diharapkan sudah terlaksana sehingga rata-rata siswa mampu memperoleh nilai tertinggi.

Berdasarkan hasil data kemampuan menganalisis siswa dapat digunakan untuk mengetahui keefektifan pembelajaran menggunakan modul biologi berbasis inquiry lab dengan perhitungan mennggunakan program SPSS 20 yaitu rumus Independent Sample t-test yang diawali oleh uji normalitas dan uji homogenitas.

Berdasarkan ringkasan mengenai hasil analisis nilai kemampuan menganalisi siswa diketahui bahwa normalitas data yang diuji menggunakan Kolmogorov-Smirnov diperoleh taraf signifikasi pre-test sebesar 0,42 dan posttest 0,200 untuk nilai Kelas Modul dan diperoleh taraf signifikasi sebesar pre-test 0,136 dan post-test 0,181 untuk kelas Exiting learning, dan kedua nilai pre-test dan Posttest Kelas Modul-Kelas Exiting learning lebih besar dari $\alpha=0,05$, sehingga $\mathrm{H}_{0}$ diterima dan mempunyai arti nilai Kelas Modul-Kelas Exiting learning berdistribusi normal. Berdasarkan hasil uji homogenitas dengan taraf signifikasi sebesar pre-test 0,596 dan post-test 0,243 keduanya lebih besar dari $\alpha$ $=0,05$, sehingga $\mathrm{H}_{0}$ diterima yang berarti variasi setiap sampel homogen.

Data hasil kemampuan menganalisis siswa dengan pre-test dan post-test Kelas Modul dan Exiting learning berdistribusi normal dan homogen, sehingga selanjutnya akan dilakukan analisis menggunakan uji Independent Sample T-Test. Berdasarkan perhitungan diperoleh hasil pre-test $=0,932>$ $\alpha=0,05$, sehingga $\mathrm{H}_{0}$ diterima. Data menunjukkan bahwa tidak terdapat perbedaan yang signifikan antara pre-test Kelas Modul dengan pre-test Exiting learning artinya kemampuan kedua kelas setara, dan perhitungan diperoleh hasil pre-test $=0,000<$ $\alpha=0,05$, sehingga $\mathrm{H}_{0}$ ditolak. Data menunjukkan bahwa terdapat perbedaan yang signifikan antara post-test Kelas Modul dengan post-test Exiting learning dengan rata-rata post-test kelas modul lebih tinggi berarti modul berbasis Inquiry $L a b$ efektif untuk meningkatkan kemampuan menganalisis siswa. Ali (2007:135) menyatakan bahwa pembelajaran menggunakan modul lebih efektif dibandingkan pembelajaran konvensional, karena menggunakan modul siswa dapat belajar secara mandiri, sehingga siswa dapat mengembangkan langkah, kebutuhan, dan kemampuan dalam belajar yang berpengaruh pada hasil belajar siswa di kelas yang diterapkan pembelajaran menggunakan modul sebagai bahan ajar siswa. Menggunakan pembelajaran berbasis Inquiry Lab siswa dapat memiliki kemampuan berpikir tingkat tinggi. Pernyataan ini sejalan dengan penelitian Berkmen, (2014) dalam yang menyatakan siswa terlibat dan dapat meningkatkan kemampuan berpikir kritis di dalam kursus laboratorium saat mereka memiliki kesempatan untuk merancang dan melakukan inquiry berbasis eksperimen yang dapat menghasilkan suatu hasil yang baru. Linn, (2004) menyatakan inkuiri dapat meningkatkan penggunaan berpikir kritis dan logis, dan pertimbangan penjelasan alternatif. Siswa akan terlibat dalam aspek-aspek tertentu dari penyelidikan mereka belajar dengan cara ilmiah untuk mengetahui alam, tetapi mereka juga harus mengembangkan kapasitas untuk melakukan penyelidikan lengkap. Penelitian dari Rooney (2009) juga menyatakan bahwa pembelajaran berbasis Inquiry dengan membuat siswa aktif dalam pembelajaran berbasis penyelidikan meliputi bertanya, meneliti dan menjawab pertanyaan kepada siswa mampu membuat siswa mandiri dan meningkatkan pemikiran tingkat tinggi.

Kemampuan berpikir tingkat tinggi terutama analisis dapat meningkatkan prestasi siswa. Pernyataan ini sejalan dengan Husain, Hafizah (2012) yang menyatakan diketahui bahwa kritis dan keterampilan berpikir analitis kalangan siswa ini pada tingkat yang sangat 
modern meningkatkan kemampuan prestasi akademik. Kemampuan menganalisis harus dimiliki siswa untuk persiapan ke jenjang pembelajaran sains. Sejalan dengan penelitian Nuangchalerm dan Thammasena (2009) yang menyatakan bahwa kegiatan pembelajaran berbasis penyelidikan dapat dipromosikan siswa baik dari segi kognitif, analitis, berpikir, dan kepuasan belajar. Harus disarankan untuk persiapan pedagogis dan memasukkan ke dalam kurikulum sains.

Pembelajaran dengan berbasis Inquiry Lab dapat membuat siswa lebih aktif dalam pembelajaran di kelas, sejalan dengan penelitian dari Hofstein, dkk (2014) yang menyatakan penting, ditemukan bahwa siswa dalam kelompok inkuiri yang memiliki pengalaman dalam mengajukan pertanyaan di laboratorium kimia mengungguli kelompok kontrol dalam kemampuan mereka baik pertanyaan maupun lebih banyak lagi. Pembelajaran dengan berbasis Inquiry Lab lebih menyenangkan, sejalan dengan penelitian Prasart, (2013) menyatakan bahwa pembelajaran laboratorium lebih menarik dan menyenangkan serta dapat meningkatkan penilaian siswa.

Pembelajaran menggunakan berbasis Inquiry Lab dapat menghubungkan antara teori dan eksperimen. Sejalan dengan penelitian dari Waters (2012) yang menyatakan bahwa inkuiri berbasis labolatorium dapat membuat siswa menjembatani kesenjangan antara teori dan praktek, menggambarkan materi yang diajarkan di kuliah, meningkatkan antusiasme dan mendorong sikap ilmiah, dan untuk mengembangkan keterampilan observasi, penalaran dan berpikir kritis.

\section{Kesimpulan dan Rekomendasi}

Kesimpulan dari penelitian dan pengembangan modul antara lain :

1. Karakteristik Modul Biologi Inquiry Lab pada Materi Sistem Gerak yang dikembangkan menggunakan sintak Inquiry Lab, yaitu observasi, manipulasi, generalisa, verifikasi dan aplikasi. Setiap kegiatan pembelajaran siswa di bimbing untuk menemukan konsep melalui aktivitas laboraturium, guru sebagai fasilitator dan modul berbasis Inquiry Lab.

2. Kelayakan Modul Biologi Inquiry Lab pada materi sistem gerak dapat digunakan sebagai bahan ajar baru di sekolah. Kelayakan didasarkan atas penilaian terhadap modul melalui uji validasi ahli materi $94,80 \%$ dengan kualifikasi sangat baik, ahli validasi pengembangan modul $84,21 \%$ dengan kualifikasi sangat baik, ahli validasi perangkat $96,55 \%$ dengan kualifikasi sangat baik, ahli validasi keterbacaan $75 \%$ dengan kualifikasi baik. uji kelompok kecil pengguna lapangan (guru dan siswa), validator praktisi (guru) 90,06\% dengan kualifikasi sangat baik, dan uji dri lapangan terbatas $81,88 \%$ dengan kualifikasi sangat baik.dan uji keefektifan yang telah sesuai dengan tujuan pengembangan.

3. Modul berbasis Inquiry Lab efektif untuk meningkatkan kemampuan menganalisis. Efektifitas modul ditunjukkan adanya perbedaan nilai kemampuan menganalisis antara kelas model Inquiry Lab $(79,36)$ dan kelas existing learning 64,75. Keefektifan Modul Biologi berbais Inquiry Lab pada materi sistem gerak telah efektif dalam memberdayakan kemampuan menganalisis siswa karena menunjukkan adanya perbedaan hasil posttest antara kelas modul dan kelas kontrol dengan nilai Sig. $=0.000<$ $\alpha=0.05$.

Rekomendasi untuk penelitian dan pengembangan modul antara lain :

1. Modul Biologi Inquiry Lab dapat diterapkan pada materi ajar sistem gerak, tetapi dalam persiapannya membutuhkan waktu ekstra supaya pembelajaran dapat berjalan dengan baik dan sesuai dengan rencana atau rancangan yang terdapat pada rancangan pelaksanaan pembelajaran yang telah dibuat sebelumnya.

2. Modul Biologi Inquiry Lab menekankan pada proses pembelajaran interaktif melalui pertanyaan-pertanyaan antar kelompok siswa maupun antara guru dan siswa, sehingga diperlukan adanya keterampilan 
dalam mengemukakan pertanyaan dan menanggapi pertanyaan dengan baik.

\section{Daftar Pustaka}

Ali, Muhammad. 2007. Guru dalam Proses Belajar Mengajar, Bandung : Percetakan Sinar Baru Algensindo Offset

Avi Hofstein, Oshrit Navon, Mira Kipnis, Rachel Mamlok-Naaman (2005). Developing Students' Ability to Ask More and Better Questions Resulting from Inquiry-Type Chemistry Laboratories

Anderson, L. W dan D.R Krathwohl. 2001. A Taxonomy Forr Learning Teaching and Assesing. New York: Longman

Borg, W. R and Gall, M. D. 1983. Education Research and introductoin. New York and Longman

Depdiknas. 2008. Teknik Penyusunan Modul. Jakarta: Direktorat PSMK

Emzir. 2012. Metodologi Penelitian Pendidikan: Kualitatif dan Kuantitatif. Jakarta : Raja Grafindo Persada.

Husain, Hafizah.2012. " The Level of Critical and Analytical Thinking Skills Among Electrical and Electronics Engineering Student, UKM". AsianSocial Science Vol 8 No.16 November 2012. pp.80-86.

Kd. Urip Astika. (2013). Pegaruh Model Pembelajaran Berbasis Masalah Terhadap Sikap Ilmiah dan Keterampilan Berpikir Kritis. Jurnal Program Pascasarjana UNIVERSITAS Pendidikan Ganesa Program Studi IPA. Volume 3, 2013

Khan, M.S. 2011. "Effect Of Inquiry Method On Achievemment Of Student In Chemistry At Secondary Level". Gilgit : International Journal of Academic Research, 3(1)

Koray, O. and Koksal, M.S. 2009. The Effect of Creative and Critical Thinking based Laboratory Applications on Creative and Logical thinking Ability of Prospective Teachers. Asia pasific Forum on Science Lerning and Teaching. 10(1): 104-114

Linn, Davis, \& Bell (2004) Guided to developing Inquiry-based materials.

Lee, Miha. The Effect of Guided Inquiry
Parappily, M.B., Siddiqui, S., Zadnik, M.G., Shapter, J., \& Schmidt, L.. (2013). An Inquiry-Based Approach to Laboratory Experiences : Investigating Student's Ways of Active Learning.

Berkmen, M.B., Murthy, C.A., and Broulidakis, M.P.. (2014) An Inquiry-Based Laboratory Module to Promote Understanding of the Scientific Method and Bacterial Conjugation.

Pohl. 2002. Learning Thinking to Learn. Tersedia di www.purdue.edu/geri

Prasart Nuangchalerm dan Benjaporn Thammasena (2009). Cognitive Development, Analytical Thinking and Learning Satisfaction of Second Grade Students Learned through Inquiry-Based Learning

Ronney, C. 2. 2009. How am I using inquiry-baset learning to improve my practice and toencourage higher order thinking among my students of mathematics? Educational Journal of Living Theories, 5, 99-27

Sugiyono. 2010. Metode Penelitian Kuantitatif Kualitatif dan R\&D : Penerbit CV Alfabeta, Bandung.

Sugiyono. 2012. Memahami Penelitian Kualitatif. Bandung: Alfabeta

Suma, K. 2005. Efektivitas Kegiatan Laboratorium Kontruktivis Dalam Meningkatkan Penguasaan Konsep-Konsep Arus Searah Mahasiswa Calon Guru. Jurnal Pendidikan dan Pengajaran . 38(2): 159171.

Suwastono. 2011. Pengembangan Pembelajaran ELearning Berbasis Moodle pada Mata Kuliah Penginderaan Jauh S-1 Jurusan Geografi Universitas Negeri Malang. Malang : PPS UM

Sofan Amri dan Iif Khoirul Ahmadi. (2010). Proses Pembelajaran Kreatif dan Inovatif dalam Kelas. Jakarta: Prestasi Pustaka.

Vajoczki, S., Watt, S., Vine, M.M., Liao, Xueqing (Rose). 2011. Inquiry Learning : Level, Discipline, Class Size, What Matters?. International Journal for the Scholarship of Teacing and Learning. Volume 5(1).

Waters, Norman C. (2012) The Advantages of Inquiry-Based Laboratory Exercises within the Life Sciences. 
ISSN: 2252-7893, Vol. 7, No. 1, 2018 (hal 71-80)

http://jurnal.uns.ac.id/inkuiri

Wenning, 2010 \& Khan 2011. "Sample Learning Sequences Based on The Levels of Inquiry Model of Science Teaching. Journal of Physics Teacher education "Online.

Wenning, C. J .2012. "Levels of Inquiry: Using Inquiry Spectrum Learning Sequnece to Teach Science". Journal of Physics teacher Education Online

Wiyanto. 2006. Menyiapkan Guru Sains

Mengembangkan Kompetensi

Laboratorium. Semarang: Unnes Press. 